\title{
Dissolution and bioactivity of a sol-gel derived borate glass in six different solution media
}

https://doi.org/10.1515/bglass-2019-0009

Received Oct 04, 2019; revised Oct 25, 2019; accepted Oct 26, 2019

Abstract: Sol-gel derived bioactive borate glasses (SGBGs) rapidly convert to hydroxycarbonated apatite (HCA) in simulated body fluid (SBF), in vitro. While previous studies have examined the influence of processing and composition on bioactivity, the effect of the in vitro dissolution media has not been well examined for these glasses. In this study, the mineral conversion of a SGBG substituted 45S5 Bioglass ${ }^{\circledR}$ formulation ("B46", (46.1) $\mathrm{B}_{2} \mathrm{O}_{3}-(26.9) \mathrm{CaO}-(24.4) \mathrm{Na}_{2} \mathrm{O}-(2.6) \mathrm{P}_{2} \mathrm{O}_{5}$, mol\%), was examined in six different dissolution media: SBF, tris(hydroxymethyl)aminomethane (TRIS, $\mathrm{pH}$ 7.4) buffer, Dulbecco's phosphate buffered saline (PBS, 1X), Dulbecco's Modified Eagle Medium (DMEM, 1X), 0.9\% Saline (SAL), and deionized water (DIW) at $1.5 \mathrm{mg} / \mathrm{mL}$ for $10 \mathrm{~min}, 2 \mathrm{~h}$, and $1 \mathrm{~d}$. All media underwent a rapid increase in $\mathrm{pH}$ as a result of glass dissolution and ion release. B46 in SBF, TRIS, and PBS converted to HCA while B46 in DMEM, SAL, and DIW converted to calcite according to attenuated total reflectance-Fourier-transform infrared spectroscopy, $\mathrm{X}$-ray diffraction, and scanning electron microscopy. The ratio of B46 to SBF was also examined at 3, 6, 12, and 24 $\mathrm{mg} / \mathrm{mL}$ for $1 \mathrm{~d}$. These results help elucidate the dissolution and mineral conversion of borate glasses and help provide insights into optimizing pre-conditioning treatments for both in vitro and in vivo analyses.

Keywords: Borate glass, sol-gel, bioactivity

\section{Introduction}

Borate-based glasses can undergo more rapid conversion to hydroxycarbonated apatite (HCA) in vitro [1-4] and in

\footnotetext{
*Corresponding Author: Showan N. Nazhat: Department of Mining and Materials Engineering, McGill University, Montreal, QC, Canada; Email: showan.nazhat@mcgill.ca

William C. Lepry, Ehsan Rezabeigi, Sophia Smith: Department of Mining and Materials Engineering, McGill University, Montreal, QC, Canada
}

vivo [5-9] compared to silicate-based glasses attributable to their higher solubility. Their ability to rapidly release ions has also implicated their use in wound healing [1014]. Depending on the type of tissue repair and chosen composition, borate glasses can also be modified to give controllable [15] and linear ion release profiles [16-18]. Furthermore, their textural properties can be enhanced by using the sol-gel processing method, which imparts high specific surface areas and porosities leading to greater reactivity and bioactivity [19-21].

Much of the acellular in vitro bioactivity assessments of bioactive glasses have used simulated body fluid (SBF) [22], or its iterations [23, 24], despite some studies that argue whether it is actually a good indicator of potential in vivo success [25-27]. Though, for now, it can still be considered as the standard for testing the reactivity of bioactive glasses, in vitro [28]. However, SBF is not the only solution used to test bioactivity, as a variety of other solutions such as tris(hydroxymethyl)aminomethane (TRIS) buffer [2934], phosphate buffer saline (PBS) [32, 33, 35, 36], cell culture media [37-41], and dilute potassium phosphate [42], as well as a range of acidic and basic solutions $[43,44]$ have been used to examine the bioactivity of glasses and their composites for various applications [27].

For borate-based bioactive glasses, SBF is commonly used for assessing their in vitro behavior; however, there are some studies that use dilute potassium phosphate $\left(0.02-0.25 \mathrm{M} \mathrm{K}_{2} \mathrm{HPO}_{4}\right)[2,45-48]$ or sodium phosphate $\left(0.025 \mathrm{M} \mathrm{Na}_{2} \mathrm{HPO}_{4}\right)$ solutions $[49,50]$. The rationale behind using these solutions is that they make the calcium content in the glass composition the limiting factor for apatite mineral formation as well as simplifying and speeding up the reactivity of the glass [15]. However, these solutions are not physiologically relevant and we have previously demonstrated that a $0.02 \mathrm{M} \mathrm{K}_{2} \mathrm{HPO}_{4}$ can give faster $\mathrm{HCA}$ conversion rates compared to $\mathrm{SBF}$ for borate-substituted Bioglass ${ }^{\circledR} 45 \mathrm{~S} 5$ melt-quench bioactive glass and therefore might give favorable bioactivity [19]. Yet, using a wide range of in vitro dissolution media, including those that can be considered as non-physiological, does offer advantages as it can give insight into the glass dissolution and ultimately bioactivity which may be useful in design-

¿ Open Access. (c) 2019 W. C. Lepry et al., published by De Gruyter. (Cc) BY 4.0 License 
Table 1: Overview of Glass Composition and Textural Properties, including Average Median $\left(D_{50}\right)$ and Mean $\left(D_{A V G}\right)$ Diameter (Particle Size), Specific Surface Area (SSA), and Average Pore Volume.

\begin{tabular}{|c|c|c|c|c|c|c|c|c|}
\hline \multirow[t]{2}{*}{ ID } & \multicolumn{4}{|c|}{ Mol \% } & \multicolumn{2}{|c|}{ Particle Size $(\mu \mathrm{m})$} & \multirow[t]{2}{*}{$\mathrm{SSA}\left(\mathrm{m}^{2} / \mathrm{g}\right)$} & \multirow[t]{2}{*}{ Pore Volume $\left(\mathrm{cm}^{3} / \mathrm{g}\right.$} \\
\hline & $\mathrm{B}_{2} \mathrm{O}_{3}$ & $\mathrm{CaO}$ & $\mathrm{Na}_{2} \mathrm{O}$ & $\mathrm{P}_{2} \mathrm{O}_{5}$ & $\mathrm{D}_{50}$ & $\mathrm{D}_{A V G}$ & & \\
\hline B46 & 46.1 & 26.9 & 24.4 & 2.6 & 39.2 & 44.8 & $94 \pm 3$ & $0.7 \pm 0.2$ \\
\hline
\end{tabular}

ing glasses for certain targeted tissue engineering applications such as hard versus soft tissue repair. The type of dissolution media is also of great importance in the preconditioning of bioactive glass in order to prevent excessive reactivity in cell culture studies [51], especially with borate glasses [52], and even for in vivo studies [53].

Therefore, the aim of this study was to examine the in vitro dissolution and bioactivity of a sol-gel-derived borate glass (SGBG) substituted 45S5 Bioglass ${ }^{\circledR}$ formulation $\left[(46.1) \mathrm{B}_{2} \mathrm{O}_{3}-(26.9) \mathrm{CaO}-(24.4) \mathrm{Na}_{2} \mathrm{O}-(2.6) \mathrm{P}_{2} \mathrm{O}_{5}\right.$; mol\%, termed "B46", in four buffered (SBF, TRIS, PBS, and Dulbecco's Modified Eagle Medium (DMEM)) and two nonbuffered (0.9 wt.\% Saline (SAL) and deionized water (DIW)) media for $10 \mathrm{~min}(0.2 \mathrm{~h}), 2 \mathrm{~h}$, and $24 \mathrm{~h}$. Changes in the media $\mathrm{pH}$ and ion release (measured through Inductively coupled plasma-optical emission spectrometry) due to glass dissolution were examined as well as their conversion to mineral via X-ray diffraction, attenuated total reflectance-Fourier transform infrared spectroscopy, and scanning electron microscopy. Furthermore, to test the in vitro bioactivity (e.g. HCA conversion) limit of B46, the influence of glass to SBF ratio $(\mathrm{mg} / \mathrm{mL})$ was examined.

\section{Materials and methods}

\subsection{Sol-gel processing}

“B46” [(46.1) $\left.\mathrm{B}_{2} \mathrm{O}_{3}-(26.9) \mathrm{CaO}-(24.4) \mathrm{Na}_{2} \mathrm{O}-(2.6) \mathrm{P}_{2} \mathrm{O}_{5} ; \mathrm{mol} \%\right]$ (Table 1) was fabricated as previously described [19]. Briefly, boric acid ( $\geq 99.5 \%$, Sigma Aldrich) and anhydrous ethanol were mixed in a watch glass-covered Teflon beaker, then magnetically stirred at $40 \pm 3^{\circ} \mathrm{C}$ to aid dissolution. Once the solution became clear, triethyl phosphate $(>99.8 \%$, Fischer Scientific), calcium methoxyethoxide (20\% in methoxyethanol, Gelest, USA) and sodium methoxide ( $25 \mathrm{wt} . \%$ in methanol, Fisher Scientific) were added in $0.5 \mathrm{~h}$ intervals. The sol was cast into polypropylene vials, sealed, and stored at $37^{\circ} \mathrm{C}$ for further gelation and ageing for 10 days. The gels were then removed from their containers and placed on crystallization dishes to dry in air at room temperature for 2 days, followed by oven drying at $120^{\circ} \mathrm{C}$ for a further 2 days. The gel was then calcined to $400^{\circ} \mathrm{C}$ at a rate of $3^{\circ} \mathrm{C} / \mathrm{min}$, with a $2 \mathrm{~h}$ dwell time, and then furnace cooled followed by sieving to a $25-75 \mu \mathrm{m}$ particle size fraction with desiccator storage until use.

\subsection{Particle characterization}

Using a Horiba LA-920 (ATS Scientific Inc., Canada) the average particle size $\left(D_{A V G}\right)$ and median diameter $\left(D_{50}\right)$ of the sieved glass powders were measured. The specific surface area (SSA) was measured with nitrogen gas adsorption and desorption isotherms collected with a Micromeritics TriStar 3000 (Micromeritics Instrument Corporation, USA) gas sorption system. SSA values were determined using the Brunauer-Emmett-Teller (BET) method [54] while the Barrett-Joyner-Halenda (BJH) method [55], using the desorption isotherms, provided the average pore width and pore volume.

\subsection{X-ray diffraction (XRD)}

The as prepared glass as well as mineral formation after immersion in the media was examined by XRD using a Bruker D8 Discover X-ray diffractometer (Bruker AXSS Inc., USA) equipped with a $\mathrm{CuK} \alpha(\lambda=0.15406 \mathrm{~nm})$ target set to a power level of $40 \mathrm{mV}$ and $40 \mathrm{~mA}$. Using an area detector, three frames were collected from $15-75$ two theta $\left(^{\circ}\right)$ and merged in post processing. Phase identification was examined using X'Pert Highscore Plus (PANalytical, Netherlands).

\subsection{Attenuated total reflectance-Fourier transform infrared (ATR-FTIR) spectroscopy}

ATR-FTIR spectroscopy was carried out using a Nicolet iS10 (Thermo Scientific) between 4000 and $500 \mathrm{~cm}^{-1}$ with a resolution of $4 \mathrm{~cm}^{-1}$ using 32 scans per sample. All spectra were normalized to the total area surface area under absorption bands. 
Table 2: Overview of Dissolution Media.

\begin{tabular}{cccccccccc}
\hline & \multicolumn{7}{c}{ Ion Concentration (mM) } \\
Media ID & $\mathrm{pH}$ & $\mathrm{Na}^{+}$ & $\mathrm{K}^{+}$ & $\mathrm{Mg}^{2+}$ & $\mathrm{Ca}^{2+}$ & $\mathrm{Cl}^{-}$ & $\mathrm{HCO}_{3}^{-}$ & $\mathrm{HPO}_{4}^{2-}$ & $\mathrm{SO}_{4}^{2-}$ \\
\hline SBF & 7.4 & 142.0 & 5.0 & 1.5 & 2.5 & 147.8 & 4.2 & 1.0 & 0.5 \\
TRIS & 7.4 & - & - & - & - & $\sim 70$ & - & - & - \\
PBS & $7-7.2$ & 146.5 & 4.2 & - & - & 139.6 & - & 11.1 & - \\
DMEM $^{*}$ & 7.4 & 155.3 & 5.3 & 0.8 & 1.8 & 119.3 & 44.0 & 0.9 & 0.8 \\
SAL & $\sim 5.5$ & 154.0 & - & - & - & 154.0 & - & - & - \\
DIW & $\sim 5.8$ & - & - & - & - & - & - & - & - \\
Blood Plasma & $7.2-7.4$ & 142 & 5.0 & 1.5 & 2.5 & 103.0 & 27.0 & 1.0 & 0.5 \\
\hline *
\end{tabular}

${ }^{\star}$ DMEM also contains amino acids, vitamins, glucose, sodium pyruvate, and phenol red

\subsection{Scanning electron microscopy (SEM)}

Samples of the glass powders were mounted on metal stubs and sputter coated with Pt prior to SEM using a Leica Microsystems EM ACE600. The morphology was examined using a field-emission SEM (Quanta 450 FEG; FEI Corporation, USA) at $5 \mathrm{kV}$.

\subsection{Dissolution media}

The in vitro mineralization of the glass was examined in six different dissolution media (Table 2). Kokubo's SBF (pH 7.4) was made as previously described [22]. The TRIS solution was prepared as previously described, where 7.55 $\mathrm{g}$ of tris(hydroxymethyl)aminomethane (Sigma-Aldrich) was added to $\sim 400 \mathrm{~mL}$ DIW at $37^{\circ} \mathrm{C}$ under magnetic stirring [30]. Then $1 \mathrm{M}$ hydrochloric acid (HCL) was added until the $\mathrm{pH}$ reached 7.4. The solution was filled to the total volume of $1 \mathrm{~L}$ and the $\mathrm{pH}$ was verified again keeping the temperature at $37^{\circ} \mathrm{C}$. The $0.9 \%$ saline solution (SAL) was prepared by adding $9 \mathrm{~g}$ of sodium chloride $(>99.5 \%$ Fisher Scientific) to $\sim 400 \mathrm{~mL}$ DIW at $37^{\circ} \mathrm{C}$ under magnetic stirring. Then, the solution was filled to the total volume of $1 \mathrm{~L}$ using DIW. DIW was obtained from a Barnstead Water Purification System $(18.2 \mathrm{M} \Omega \cdot \mathrm{cm})$. Dulbecco's phosphate buffer solution (PBS, 1X, without calcium or magnesium, Gibco ${ }^{\circledR}$ by Life Technologies ${ }^{\mathrm{TM}}$ ) and Dulbecco's Modified Eagle Medium (DMEM, 1X, modified, without calcium chloride and magnesium but with $4.5 \mathrm{~g} / \mathrm{L}$ glucose, L-glutamine, sodium pyruvate and phenol red, MultiCell, Wisent Bioproducts) were used as received.

\subsection{Bioactivity}

Glass powder $(\mathrm{n}=3)$ was added to sterile $50 \mathrm{~mL}$ falcon tubes containing the dissolution media at $37^{\circ} \mathrm{C}$ using $1.5 \mathrm{mg} / \mathrm{mL}$ ratio and stored at $37 \pm 1^{\circ} \mathrm{C}$ for $10 \mathrm{~min}(0.2 \mathrm{~h}), 2 \mathrm{~h}$, and $24 \mathrm{~h}$. The vials were gently agitated during the first addition. At each time point the remaining glass was rinsed with deionized water then twice with anhydrous ethanol followed by drying in an oven at $60^{\circ} \mathrm{C}$ for $1 \mathrm{~d}$. The $\mathrm{pH}$ of the SBF solution was measured $(n=3)$ at each time point using an Orion Star ${ }^{\mathrm{TM}}$ A211 $\mathrm{pH}$ meter (Thermo Scientific ${ }^{\mathrm{TM}}$ ). In an additional experiment using SBF, the glass powder was added at $3,6,12$, and $24 \mathrm{mg} / \mathrm{mL}$ ratios for $1 \mathrm{~d}$.

\subsection{Inductively coupled plasma-optical emission spectrometry (ICP-OES)}

In each dissolution medium, the release of boron, calcium, and phosphorus ions from glass were quantified using an ICP-OES (Thermo Scientific iCAP 6500, USA). Aliquots $(n=3)$ from the falcon tubes were filtered through a $0.2 \mu \mathrm{m}$ nylon filter and stored in a $15 \mathrm{~mL}$ falcon tube to which $4 \%$ $(w / v)$ nitric acid (Fisher Scientific, Canada) was added followed by dilution. Serial diluted standards of boron $(0.5,5$, $50 \mathrm{ppm}$ ), calcium (0.2, 2, $20 \mathrm{ppm})$, and phosphorous (0.1, $1,10 \mathrm{ppm})$ were used.

\section{Results}

\subsection{Characterization of the as prepared B46}

Table 1 shows the composition (mol\%) as well as the mean $\left(\mathrm{D}_{A V G}\right)$ and median $\left(\mathrm{D}_{50}\right)$ particle size of the as prepared glass powders, which were $44.8 \mu \mathrm{m}$ and $39.2 \mu \mathrm{m}$, respectively. The SSA $\left(94 \pm 3 \mathrm{~m}^{2} / \mathrm{g}\right)$ and pore volume $(0.7 \pm 0.2$ $\mathrm{cm}^{3} / \mathrm{g}$ ) were similar to our previously reported values for B46 $[19,21,56]$. Figure 1a shows the ATR-FITR spectrum of the $\mathrm{B} 46$ particles, which indicated three main regions that include: $\mathrm{B}-\mathrm{O}$ stretching of $\mathrm{BO}_{4}$ units $\left(850-1200 \mathrm{~cm}^{-1}\right)$, 

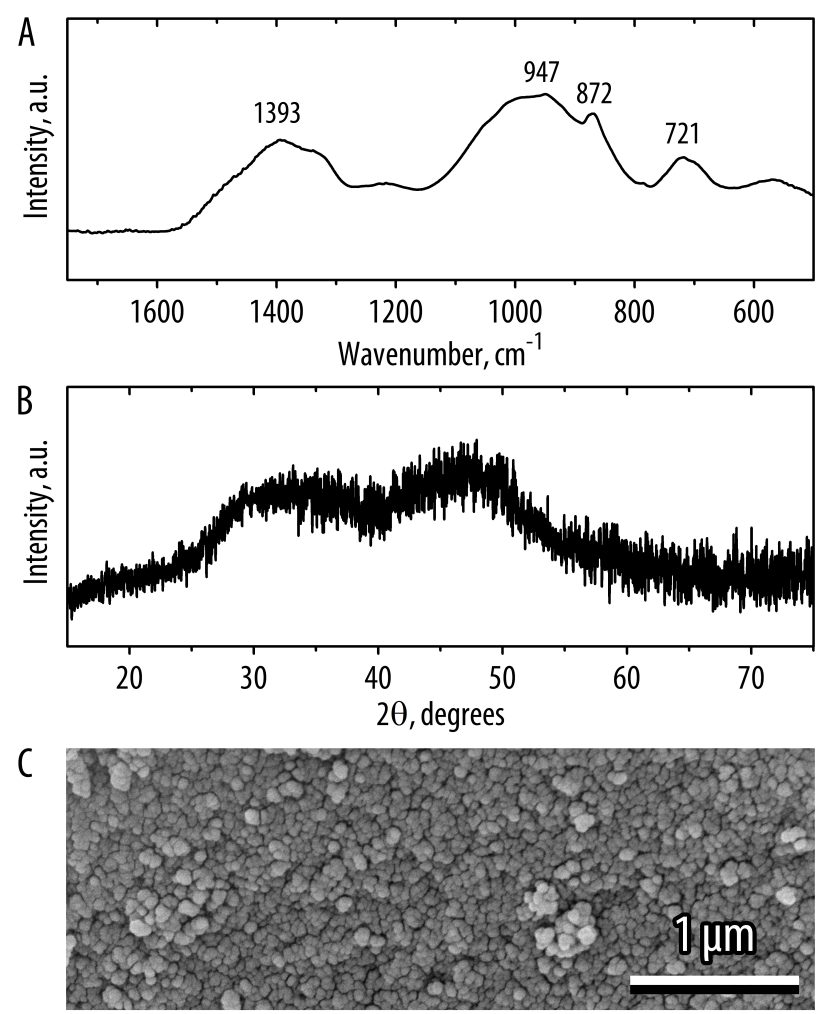

Figure 1: Characterization of as-made B46 (a) ATR-FTIR spectrum, (b) XRD diffractograph, and (c) SEM image.

B-O stretching of $\mathrm{BO}_{3}$ units $\left(1200-1500 \mathrm{~cm}^{-1}\right)$, and the $\mathrm{B}-\mathrm{O}-\mathrm{B}$ bending of the $\mathrm{BO}_{3}$ band $\left(\sim 720 \mathrm{~cm}^{-1}\right)$ [57-59]. The $\mathrm{B}-\mathrm{O}$ linkages of $\mathrm{BO}_{4}$ can be observed around the broad band at approximately $1000 \mathrm{~cm}^{-1}$ and the $\mathrm{B}-0$ stretching of boroxoal rings is observed at the defined shoulder peak $\sim 870 \mathrm{~cm}^{-1}$ [60-63]. XRD confirmed the amorphous nature of the glass through the characteristic broad humps (Figure 1b), while SEM showed the fine, textured surface of the glass (Figure 1c), corresponding to the enhanced textural properties (Table 1) from the sol-gel process.

\subsection{Bioactivity}

ATR-FTIR spectra of B46 submersed in all dissolution media indicated mineral formation within $0.2 \mathrm{~h}$. For SBF, TRIS, and PBS, a strong band at $\sim 1020 \mathrm{~cm}^{-1}$ and a shoulder region at $\sim 961 \mathrm{~cm}^{-1}$, indicated the bending modes $v 1$ of $\mathrm{PO}_{4}^{3-}$ [64] (Figure 2a). Also observed are the stretching modes $v 1$ and $v 3$ of $\mathrm{CO}_{3}^{2-}$ at $\sim 1470$ and $\sim 1421 \mathrm{~cm}^{-1}$, respectively, along with a sharp peak at $\sim 870 \mathrm{~cm}^{-1}$, indicating the bending mode $v 2$ of $\mathrm{CO}_{3}^{2-}[65,66]$. The $870 \mathrm{~cm}^{-1}$ band is likely a combination of the $\mathrm{B}-\mathrm{O}$ stretching of boroxoal rings found in the as prepared glasses as well as the bending mode $v 2$ of $\mathrm{CO}_{3}^{2-}$. The $v 2$ bending mode of water can also be seen by the broad band at $\sim 1640 \mathrm{~cm}^{-1}[67,68]$ that was most visible in SBF. The peaks around 560 and 600 $\mathrm{cm}^{-1}$, representative of $\mathrm{P}-\mathrm{O}$ bending bands, do not suggest HA or HCA formation, but rather indicate the presence of orthophosphate lattices $[28,69]$. Despite this, the longer submersion times suggest greater extent of HCA formation in these three media.

ATR-FTIR spectra of B46 submersed in DMEM, SAL, and DIW showed peak formation consistent with calcite, as indicated by the asymmetric stretch $(v 3) \sim 1400 \mathrm{~cm}^{-1}$ and the out-of-plane bending $(v 2)$ vibration at $\sim 875 \mathrm{~cm}^{-1}$ $[70,71]$ along with the $v 4 \mathrm{CO}_{3}^{2-}$ in plane bending at $\sim 707$ $\mathrm{cm}^{-1}$. Also, observed is the large $v 1$ of $\mathrm{PO}_{4}^{3-}$ at $\sim 1020 \mathrm{~cm}^{-1}$ and the $\mathrm{P}-\mathrm{O}$ bending band at $\sim 560 \mathrm{~cm}^{-1}$ which were observed in the samples submersed in SBF, TRIS, and PBS.

In line with the ATR-FTIR data, XRD diffractographs indicated two different mineral formations, depending on the type of dissolution media (Figure 2b). Characteristic HCA conversion was observed in SBF, TRIS, and PBS by the main peak at $\sim 25$ and $\sim 32^{\circ} 2 \theta$ (“•”, JCPDS 19-272) within $2 \mathrm{~h}$ which became more defined at $1 \mathrm{~d}$. The fairly broad apatite peaks suggest nanometer-sized or partially crystallized HCA [2]. On the other hand, samples submerged in DMEM, SAL, and DIW converted to calcite as seen by the characteristic peak at $\sim 29^{\circ} 2 \theta$ (“口”, JCPDS 5-586) which also began forming within $0.2 \mathrm{~h}$ of submersion (Figure $2 \mathrm{~b}$ ). In these three samples, the peaks become more defined with longer submersion times. However, for samples submerged in SAL and DIW, the main HCA peak $\sim 32^{\circ} 2 \theta$ also began to form by $1 \mathrm{~d}$ suggesting a combination of HCA and calcite mineral formation. SEM images provided a visual representation of the mineral phases formed after 1d (Figure 3). B46 in SBF, TRIS, and PBS showed typical, flowerlike HCA crystals, while samples in DMEM, SAL, and DIW showed more geometric, rod-like crystals typical of calcite formation.

\subsection{Ion release and $\mathrm{pH}$}

The $\mathrm{pH}$ change and ion release through $\mathrm{B} 46$ dissolution in each dissolution medium are presented in Figure 4. The $\mathrm{pH}$ increased rapidly in all media within $0.2 \mathrm{~h}$, which then became stable (Figure 4a). SBF and TRIS resulted in similar $\mathrm{pH}$ values along with the smallest overall increase $(\mathrm{pH}$ 7.8) similar to what has previously been observed in B46 in SBF [19]. DMEM underwent the next highest $\mathrm{pH}$ increase to $\sim 8.3$ while PBS increased to $~ 9.1$. The non-buffered solutions; SAL and DIW, had the highest overall $\mathrm{pH}$ increase, $\sim 9.6$ and $\sim 9.7$, respectively, which are similar to previously reported values [21]. 

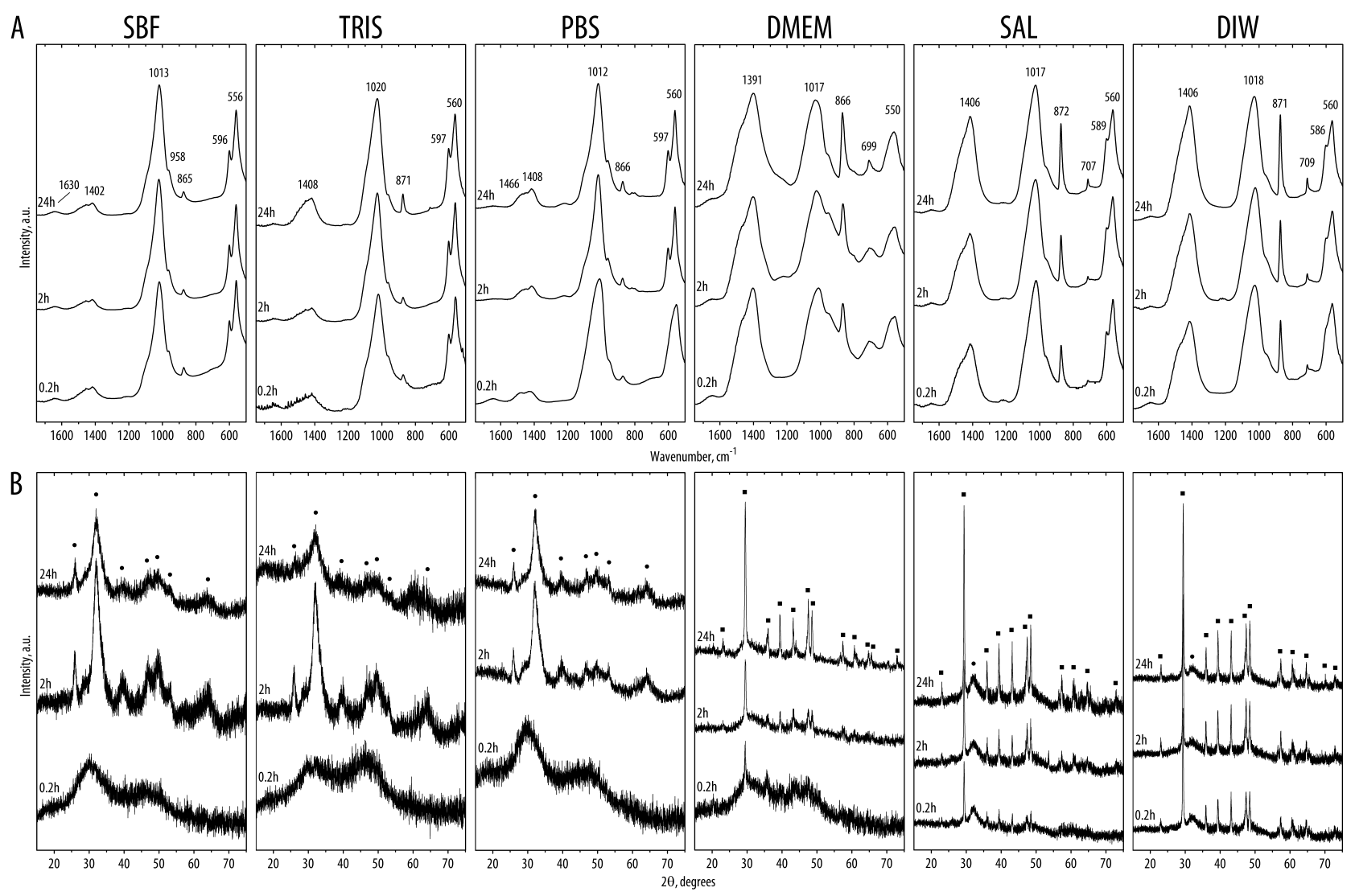

Figure 2: Conversion of B46 in different submersion media. (a) ATR-FTIR spectra, and (b) XRD diffractograms as a function of immersion time. B46 in SBF, TRIS, and PBS show typical HCA formation (“•” JCPDS 19-272) while in DMEM, SAL, and DIW show calcite formation (“口” JCPDS 5-586). With longer dissolution times, SAL and DIW began to show characteristic HCA according to XRD.
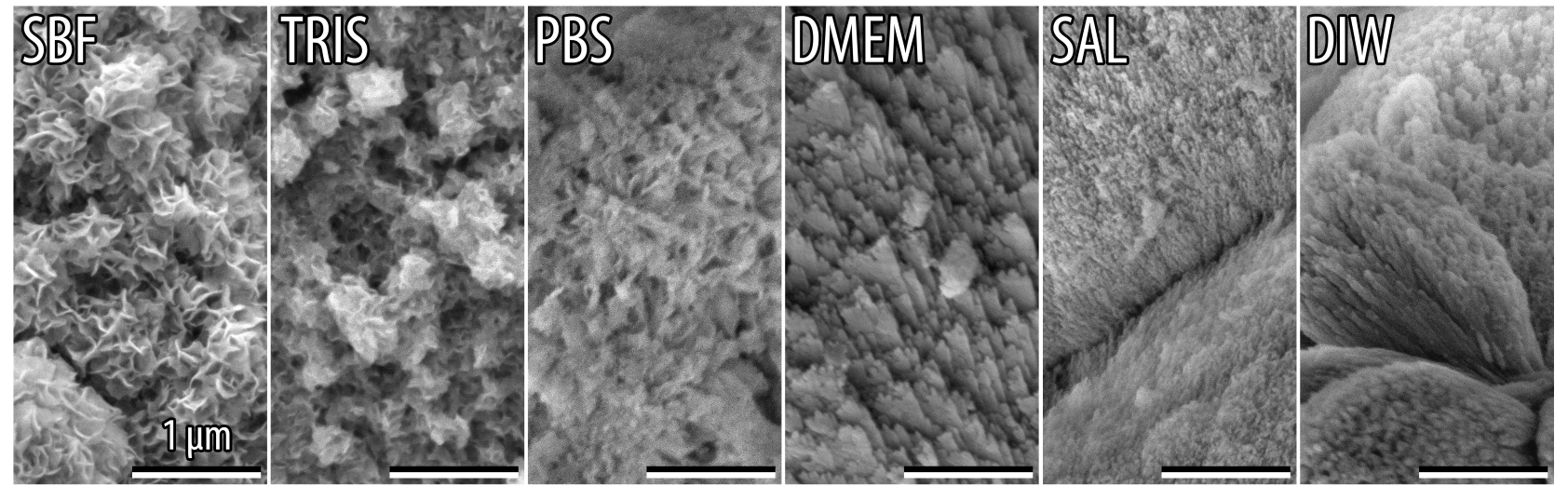

Figure 3: SEM images of B46 after 1d of submersion in different dissolution media. B46 submerged in SBF, TRIS, and PBS show characteristic HCA crystals, while in DMEM, SAL, and DIW, it shows typical calcite crystals. Scale bar $=1 \mu \mathrm{m}$.

ICP-OES showed a rapid then fairly steady release of boron in each of the dissolution media (Figure 4b). Initially, B46 in SAL and DIW had the lowest boron release rate but ended up with the highest total release at 1d. Calcium release rates in TRIS and SBF were initially high and remained static until 1d while in SAL and DIW, it showed increasing release rates. DMEM was the only medium which showed a decreasing calcium release rate. In PBS, however, calcium release was very limited at all time points. Phosphorous release was initially rapid for SBF, TRIS, and DMEM then showed a slightly decreasing trend [19] (Figure 4d). Phosphorous levels in SAL and DIW 

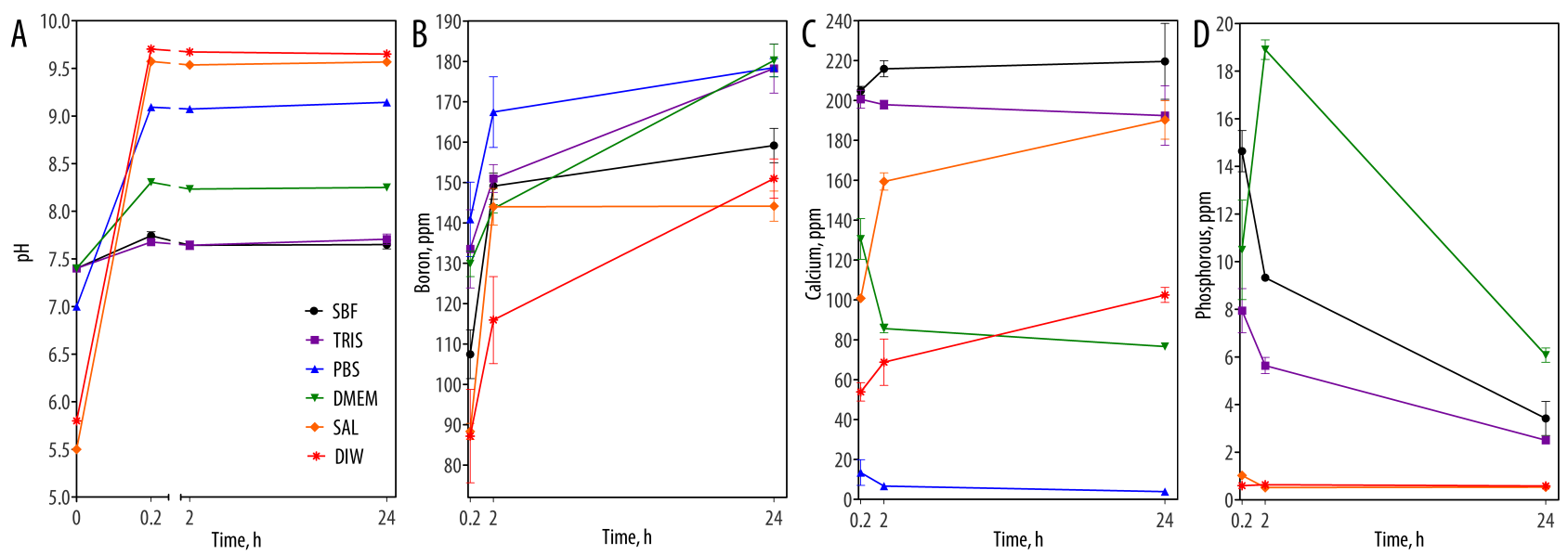

Figure 4: B46 dissolution in different media. (a) pH, and release of (b) boron, (c) calcium, and (d) phosphorous in each dissolution medium up to day 1 (24h).

were low with a very small drop overtime. Due to the already high content of phosphorous in PBS, the trend is not shown. This decrease in phosphorous is a known indicator of HCA formation [28], which has previously been observed to take place between $1 \mathrm{~d}-3 \mathrm{~d}$ immersion in DIW [19] and $6 \mathrm{~h}-1 \mathrm{~d}$ in SBF [21] for B46. Furthermore, the release rates of boron and calcium are similar to previous studies in DIW [19] and SBF [21].

\subsection{Effect of glass to SBF ratio}

The B46 powder was submersed in SBF at 1.5, 3, 6, 12, and $24 \mathrm{mg} / \mathrm{mL}$ for $1 \mathrm{~d}$ in SBF. With increasing glass to SBF ratio, the $\mathrm{pH}$ became higher and began to stabilize at around 9.1 at $24 \mathrm{mg} / \mathrm{mL}$ (Figure 5a). ATR-FTIR spectra (Figure $5 \mathrm{~b}$ ) showed the characteristic aforementioned phosphate peak formation up to $6 \mathrm{mg} / \mathrm{mL}$ that became less defined, and similar to the calcined glass at 12 and $24 \mathrm{mg} / \mathrm{mL}$. XRD patterns (Figure 5c), indicated typical HCA peak formation at the ratios of 1.5 and $3 \mathrm{mg} / \mathrm{mL}$, however, at 6 $\mathrm{mg} / \mathrm{mL}$ calcite peaks began to form which became slightly less defined at $12 \mathrm{mg} / \mathrm{mL}$. This is in slight contrast to the ATR-FTIR spectra which did not show calcite-like peaks at 6 or $12 \mathrm{mg} / \mathrm{mL}$ as observed in Figure 2a. Finally, no crystalline peaks were detected in the XRD of the highest in vestigated ratio of $24 \mathrm{mg} / \mathrm{mL}$ (Figure $5 \mathrm{c}$ ), and the sample remained amorphous, which supports the ATR-FTIR data.

\section{Discussion}

While the definition of bioactivity for glasses is continuously evolving, as they are being considered for non- mineralizing tissue engineering applications [72], there remains a great need to better understand their dissolution and mineral conversion behaviour. The majority of these studies are performed on silica-based glasses in SBF, though this medium might not be the best bioactivity indicator for all glass systems. Therefore, to better understand the dissolution and bioactivity of a sol-gel derived bioactive borate glass composition (B46), six different dissolution media were investigated which converted the glass to HCA or calcite. Furthermore, to explore the limits of bioactivity, the effect of glass to SBF ratio on mineral conversion was also investigated. By using one glass composition, we can better decipher the effects of each media and concentration without influence from compositional or textural differences in the glass which are known to influence the dissolution and bioactivity behaviour.

\subsection{Media that formed apatite - SBF, TRIS, and PBS}

TRIS was first made by Gomori [73] and since it is stable over time and can be inert with other solution ingredients, it was proposed for biological research [74]. In fact, some of the first glass dissolution studies on $45 \mathrm{~S} 5$ Bioglass ${ }^{\circledR}$ were performed in TRIS buffer solutions, which were first referred to as either "simulated body conditions" or "simulated body fluids" [75-77]. Later, Kokubo developed SBF to evaluate apatite mineral formation for an A-W glassceramic, in vitro, which was not possible using TRIS [23]. $\mathrm{SBF}$, which is currently commonly used to assess bioactivity in general [22], was developed to simulate human blood plasma and is kept at a neutral $\mathrm{pH}$ using TRIS as a buffer. It has also been brought into question whether 


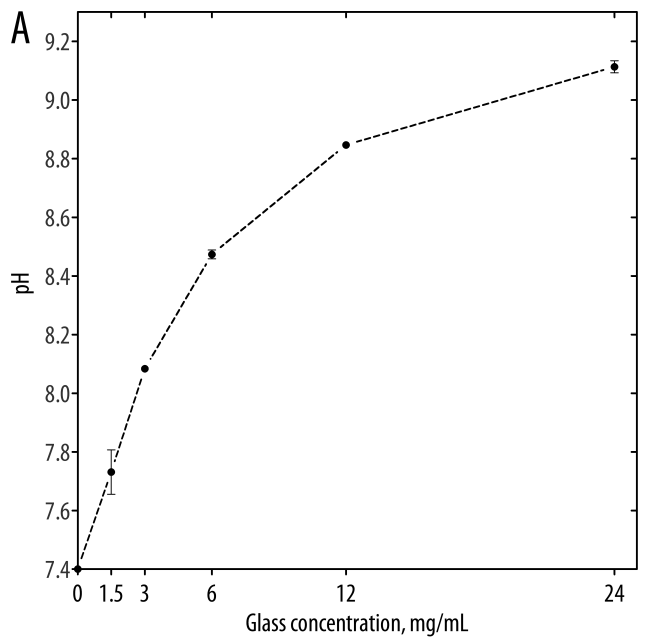

B

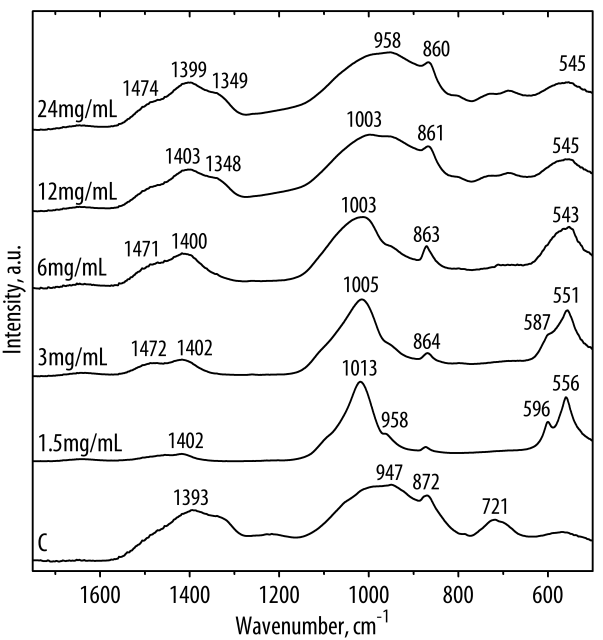

C

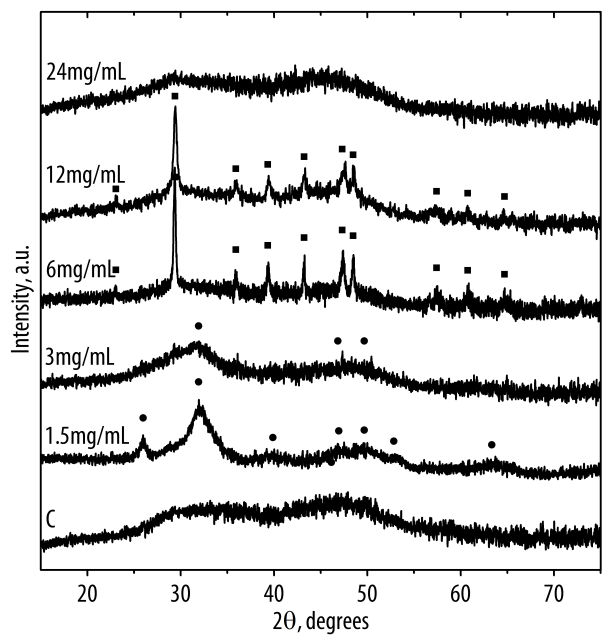

Figure 5: Effect of different B46 to SBF ratios on glass conversion in SBF. (a) pH and the resultant mineral formation according to (b) ATR-FTIR and (c) XRD at various concentrations submerged in SBF for up to day 1. Typical HCA ("•"JCPDS 19-272) and calcite formation ("口" JCPDS 5-586) are seen in (c). Dashed line in (a) used to guide the eye.
TRIS is the appropriate buffer to use in SBF since it has been shown to accelerate the dissolution of glass-ceramic scaffolds [78]. This has led to the use of other buffers such as HEPES (4-(2-hydroxyethyl)-1-piperazineethanesulfonic acid) to create a revised-SBF ( $\mathrm{r}-\mathrm{SBF}$ ) or modified-SBF (m$\mathrm{SBF}$ ) that have lower $\mathrm{Cl}^{-}$and higher $\mathrm{HCO}_{3}^{-}$, respectively [79, 80]. However, TRIS, is still commonly used alone as a simplified medium to study dissolution [81] as it lacks the high amounts of Ca and P found in SBF (Table 2), which can interfere with the ion release kinetics and making mineral formation more challenging [82]. Thus, changing the type of SBF [23, 24, 79, 80], or TRIS [43, 81] will also influence the dissolution kinetics and mineralization. Nevertheless, despite ongoing debates [25-27], SBF is still considered as the standard for the acellular bioactivity testing of bioactive glasses [28] as well as of other inorganic biomaterials (ISO:23317:2014 Implants for surgery - in vitro evaluation for apatite-forming ability of implant materials).

In this study, the $\mathrm{pH}$ values in both TRIS and SBF were similar along with the ion release kinetics. Mineralization was detected slightly earlier in SBF according to $\mathrm{XRD}$, which is likely due to the presence of excess Ca and $\mathrm{P}$ ions in solution, but similar peaks were observed in ATRFTIR. This is in contrast to a recent study, which showed that apatite formation is slower when melt-quench $45 \mathrm{~S} 5$ is submersed in SBF compared to TRIS [83]. Our finding might be due to the higher solubility of B46 coupled with the enhanced textural properties which speed up apatite conversion. By $2 \mathrm{~h}$, glass in both media showed strong HCA formation via XRD as well as typical HCA crystals at $1 \mathrm{~d}$. These conversion rates are rapid compared to traditional melt-derived 45S5, S53P4, and 13-93 glasses where the consensus for the first indication of HCA formation for both XRD and FTIR were at $24 \mathrm{~h}, 72 \mathrm{~h}$, and $168 \mathrm{~h}$, respectively [28] compared to $2 \mathrm{~h}$ in this study. On the other hand, in a series of three-component silica sol-gel glasses, the first indication of HCA formation was observed within $5 \mathrm{~h}$ for both SBF and TRIS according to FTIR (no XRD was performed) [84].

It has recently been shown that there is complexation of boron by TRIS in borosilicate glasses which increased the rates of dissolution [85]. In this study, we did not observe a significant difference in boron release rates, which may be due to the greater SSA and porosity of B46 making the ion release rapid for all elements within the glass. However, calcium release was similar in both SBF and TRIS, despite TRIS not having $\mathrm{Ca}^{2+}$ ions. It was previously shown that, TRIS can accelerate scaffold degradation causing the $\mathrm{Ca}^{2+}$ concentration to be nearly twice the original value in SBF during the first $8 \mathrm{~h}$ of immersion [78]. Here, $\mathrm{Ca}^{2+}$ amount in ICP-OES was nearly double that compared to DIW at the $2 \mathrm{~h}$ and $24 \mathrm{~h}$ time points. This might further show 
that the complexing of borate with TRIS greatly increases the glass solubility allowing for all the $\mathrm{Ca}^{2+}$ ions to be released [85], although further studies are needed to confirm this.

Similar to TRIS, PBS is another simple buffer solution that has been used to examine glass bioactivity. For example, it was previously shown that, when compared to SBF and TRIS, PBS led to faster apatite conversion of 45S5, S53P4, 1-98, and 13-93 bioactive glass compositions, which can be attributed due to its higher concentration of phosphorous ions [33]. However, the results of that study are difficult to interpret since they compare granules (45S5 and S53P4) and fibers (1-98 and 13-93) through SEM-EDXA and ion release, not XRD and FITR. In our study, a HCA layer was observed in PBS at a similar time to SBF which were both slightly faster than TRIS, according to XRD. It was also hypothesized that this faster formation created a calcium-phosphate layer which further slowed the dissolution process [33]. Furthermore, it was noted that sodiumbuffered PBS has a lower buffering capacity since the release of alkali and alkaline earths result in higher $\mathrm{pH}$ values and thus, higher calcium-phosphate precipitation. This was observed in this study, as the $\mathrm{pH}$ increase in PBS was higher compared to those in SBF and TRIS. Furthermore, the release of calcium was significantly hindered compared to all other dissolution media. This confirms the aforementioned hypothesis that a rapid HCA layer was formed, which slowed the overall dissolution process. Despite the overall reduced calcium release, its initial release from the glass was apparently sufficient to induce rapid HCA formation. This observed effect is likely enhanced by the higher SSA and porosity of B46 allowing for faster dissolution and mineral conversion.

\subsection{Media that formed calcite - DMEM, SAL, and DIW}

DMEM is one of the most universally used media for cell and tissue culture and is supplied in either buffered or nonbuffered forms. It has also been proposed as an easier and more reproducible medium to test bioactivity [39] and is an obvious choice for pre-conditioning studies involving cells. In our study, calcite formation was observed within 10 min of submersion in DMEM. Previously, Theodorou et al. [38] observed amorphous apatite formation in some areas of 45S5 glass and crystalline carbonated apatite on sol-gel derived $58 \mathrm{~S}$ glass within three days. It was speculated that the adsorption of proteins from the DMEM on the amorphous calcium-phosphate layer inhibited apatite formation. Alpha-MEM has previously shown to reduce min- eral formation compared to SBF in melt-quench $45 \mathrm{~S} 5$ and sol-gel derived $58 \mathrm{~S}$ glasses since the serum delays the glass surface reactions [86]. This inhibition was also apparent in this study. Furthermore, the pH in DMEM ( 8.3) was lower than that of PBS ( 9.1), yet calcite formation was still preferred over HCA according to ATR-FTIR, XRD, and SEM. This might be due to the higher calcium and carbonate content of DMEM, which would favor calcite formation [87]. Calcium release in DMEM decreased the most compared to the other media, which may suggest re-precipitation as was also observed in the case of phosphorus release.

Recently, a DMEM/fetal bovine serum FBS solution was used to examine the dissolution of high borate containing, ternary glasses, though the glass conversion was not reported [88]. A non-buffered and modified buffered DMEM was also tested on 45S5 glass-ceramic scaffolds, where it was shown to initially form calcite, amorphous calcium phosphate as well as halite [40]. Although the study did not examine a particulate form, the authors suggested that the non-buffered modified-DMEM solution is not ideal for monitoring bioactivity since there is no development of an apatite phase. In another study on bioactive glass coatings, it was stated that "DMEM-like media supplemented with proteins under correct homeostatic conditions are more appropriate and truthful assays to assess in vitro biomineralization capacity" compared to SBF [41]. The authors suggested that the SBF is already supersaturated with apatite components [25] and that biomineralization is obligatory due to the rapid $\mathrm{pH}$ increase.

Although SAL is not physiological, it is still commonly used in medicine [89]. SAL has also not been as widely explored as an in vitro dissolution medium even though it, along with the patients' blood, are deemed suitable for mixing commercially available bioactive glasses such as 45S5 Bioglass ${ }^{\circledR}$ and S53P4 BonAlive before human implantation. These glasses are melt-quench silicates and therefore react slower compared to B46 especially in the brief mixing step before implantation. This might also be why DIW has been rarely studied as a dissolution medium for bioactive glasses even though water can be used in combination with the patient's own saliva, to help stimulate glasses for dental use. However, since the SSA and porosity of sol-gel glasses is significantly increased, the reaction during this preconditioning step will become more important. A study examining a silicate-based glass-ceramic scaffold in DIW showed that the initial crystal phases remained unchanged according to XRD and SEM after the dissolution period [78]. Furthermore, other studies that have focused on the effect of DIW on the glass surface [90, 91] and interactions with water vapour have shown conversion of $45 \mathrm{~S} 5$ glass to various mineral phases including 
NaP, CaP, $\mathrm{CaSiO}_{4}, \mathrm{Ca}_{10} \mathrm{Na}\left(\mathrm{PO}_{4}\right)_{7}$, and $\mathrm{NaCaPO}_{4}$ [92]. For borate glasses, although previous studies have analyzed the dissolution of ternary and quaternary compositions in DIW, their resultant conversion to mineral was not examined $[93,94]$. We are unaware of any study that has used $\mathrm{XRD}$ to examine bioactive glass-mineral conversion in SAL or DIW.

In this study, submersion of B46 in SAL and DIW resulted in the highest increase in $\mathrm{pH}$ and converted to calcite within 10 min according to ATR-FTIR and XRD as well as showing typical calcite crystals in SEM images. XRD also showed the formation of the primary HCA peak for SAL and DIW at 1d suggesting that two phases were forming which has been previously observed in silica sol-gel glass in SBF [95] and fluorinated melt-quench glasses in DMEM [96].

Other studies involving calcite have shown the formation of a weaker band around $1082 \mathrm{~cm}^{-1}[71,97,98]$ that are typically seen in Argonite and Valerite [71], but these were not observed here. Instead the area is dominated by the large $v 1$ of $\mathrm{PO}_{4}^{3-}$ at $\sim 1020 \mathrm{~cm}^{-1}$ [64], which was seen in the samples submersed in SBF, TRIS, and PBS. Similarly, the P-O bending bands at $\sim 560$ and $\sim 600 \mathrm{~cm}^{-1}$, indicating an orthophosphate lattice $[28,69]$ are also present. The rapid $\mathrm{pH}$ increase and calcite conversion via ATR-FTIR was previously observed with 45 S5 Bioglass in DIW after $2 \mathrm{~d}$ [81]. It can be speculated that this is likely due to the fact that both SAL and DIW are not buffered, allowing for the faster formation of Ca-containing salts which are less soluble at higher $\mathrm{pH}$. Furthermore, there is also an abundance of atmospheric $\mathrm{CO}_{2}$ which are introduced into the solution [81, 99].

Although not as common as other ceramics, calcite is a known bone graft substitute that bonds to bone without the formation of a surface apatite layer $[100,101]$ as can be observed with other bioactive ceramics and glasses [102]. In fact, calcite formation might be favorable as calcite scaffolds can promote better bone marrow induced osteogenesis when compared to hydroxyapatite scaffolds [103]. Furthermore, calcite has been shown to induce faster osteoclast remodeling in vitro when compared to synthetic and natural hydroxyapatite [104] as well as tricalcium phosphate [105]. Despite its relevance, calcite is often "ignored" during bioactivity assessments [87]. Perhaps this is because bioactive glasses often convert to HCA, especially in vitro. As stated above, one of the key reasons for developing SBF was to observe apatite formation which is also a key requirement for the ISO standard (23317). However, previous studies have also shown that, silicate bioactive glasses [106, 107] as well as nano 45S5 glass [108] can convert to calcite in SBF. Indeed, particle size, choice of media, and ratio will all influence calcite formation, which usually forms at the expense of HCA. For example, finer particle size fractions of 13-93B3 borate glass have demonstrated calcite formation [109] and borate glass fibers were shown to convert to calcite in vivo due to higher amounts of metal dopants in their compositions that inhibited calcium-phosphate formation [110]. Taken together, glass-calcite conversion should still be considered as an indicator of bioactivity and may even be preferred in some applications.

\subsection{Effect of glass to SBF ratio}

The current ISO standard (23317) for testing bioactive materials is aimed for solid, monolithic materials at a fixed surface area to volume ratio and not ideally designed for bioactive glass particles. The recently modified ISO standard takes this into consideration and suggests using 75 $\mathrm{mg}$ of glass powder $(45-90 \mu \mathrm{m})$ for $50 \mathrm{~mL}$ of SBF (i.e., 1.5 $\mathrm{mg} / \mathrm{mL}$ ) regardless of the SSA of the material [28]. Previous work on melt-quench $45 \mathrm{~S} 5$ glass powder showed that, calcite formed at higher concentrations $(15 \mathrm{mg} / \mathrm{mL})$ as detected by XRD [106]. The authors proposed that calcite formed at the expense of HCA since the ratio of $\mathrm{Ca} / \mathrm{P}$ ions increased with increasing glass concentration which also increased the $\mathrm{pH}$ of the solution favoring calcite formation. The concentration where HCA formation became inhibited for melt-derived $45 \mathrm{~S} 5$ was found to be at $2 \mathrm{mg} / \mathrm{mL}$ [106]. However, in the same study it was shown that sol-gel $58 \mathrm{~S}$ glass did not convert to calcite, where HCA was formed at a range of concentrations $(1-15 \mathrm{mg} / \mathrm{mL})$ with a much smaller HCA reduction compared to the $45 \mathrm{~S} 5$ glass due to its mesoporous texture [106].

In this study, the $\mathrm{pH}$ of SBF increased with increasing glass content, which is likely due to the large number of ions being released during dissolution. Interestingly, and according to XRD, a ratio of up to $3 \mathrm{mg} / \mathrm{mL}$ led to HCA formation, while the range from 6 to $12 \mathrm{mg} / \mathrm{mL}$ formed calcite, and no mineralization was observed at $24 \mathrm{mg} / \mathrm{mL}$. However, typical phosphate peaks were only observed in the ATR-FTIR spectra of $1.5,3$, and $6 \mathrm{mg} / \mathrm{mL}$ and there was no indication of calcite peaks. In this study, the dissolution environment was mainly static as the vials were only agitated twice during the $1 \mathrm{~d}$ test period. If the glasses were under constant stirring, it can be speculated that the conversion would be even more rapid and occur at a greater extent. This might explain why the ATR-FTIR, which is a surface analysis technique, does not decipher between the typical phosphate peaks related to HCA and calcite formation. 
While most studies on dissolution media have focused on melt-derived, silicate glasses, the effects are enhanced when dealing with highly reactive SGBGs, suggesting that dissolution media selection is much more critical, especially for pre-conditioning treatments. Although not examined in this study, it is also anticipated that changing the particle size range of B46 will influence ion release and conversion rates of these glasses. Since many in vivo studies typically use higher particle size fractions, it is anticipated that SGBGs will react more slowly in vivo which has been observed in other silicate $[28,86]$ and meltquench borate [109] glasses. As B46 has also been added to a degradable polymeric scaffold [111], it would useful to examine the autocatalytic affects of acidic environments as the polymer degrades [44] or simulates a bacterial in fection [112]. For instance, 45S5 Bioglass ${ }^{\circledR}$ submersed in lower $\mathrm{pH}(\mathrm{pH}=4)$ solutions was shown to have faster ion release, but comparable apatite formation compared to neutral, $\mathrm{pH}=7.4$ solutions [43]. However, when the solution $\mathrm{pH}$ was increased, limited apatite formation was observed due to the lower ion release rate [43]. While $\mathrm{H}_{3} \mathrm{BO}_{3}$ solutions at different $\mathrm{pH}$ values have been examined [113], there is still a need to analyse how glasses react and convert at these different values.

It is abundantly clear that the type of dissolution medium plays a significant role in dictating the conversion of B46, in vitro. We found that SBF, TRIS, and PBS convert the glass to HCA while DMEM, SAL, and DIW favor calcite formation. The high SSA and porosity values of B46 allow for rapid conversion to mineral, but the quantities and types of ions released do not necessarily dictate what mineral is formed as was seen with PBS and DMEM. Furthermore, even at a higher glass to media ratio, bioactivity is still observed in SBF. It is also anticipated that using a dynamic in vitro environment and changing the particle size will affect the rates and possibly types of mineral conversion of SGBGs. Regardless, this study emphasizes the importance of media selection in the pre-conditioning and testing of sol-gel derived bioactive borate glasses.

While it is important to recognize the effect of different dissolution media, we think the recent round robin study examining glass particles in SBF [28] gives best and most robust guide for evaluating in vitro bioactivity. This is despite of the fact that SBF has been called into question [2527] and that bioactive glasses are being used specifically for soft tissue repair [72] where mineralization may not always be desirable [14]. In particular, their guidelines of initial glass characterization (i.e., particle size, surface area, and XRD) and evaluation of the altered glass using quantifiable techniques (i.e., FTIR, XRD, and ICP-AES/OES/MS) greatly help interpret results from multiple studies regard- less of the dissolution medium used. Although not discussed in this paper, these parameters should also hold true for dental applications since there are many different formulations of artificial saliva used in vitro [114-117]. For non-mineralizing applications, such as wound healing, ion release measurements become more critical as the released ions help stimulate the body's natural repair mechanisms. For in vitro testing in these scenarios, it might be beneficial to use both a simple (e.g. TRIS or DIW) and inorganic ion-containing medium (e.g. SBF or DMEM) to help develop a more robust assessment of the ion release kinetics.

Acknowledgement: This study was funded by Canada NSERC, FRQNT, and CFI. W.C.L. is supported by McGill University Faculty of Engineering Innovation Fellowship. E.R. is supported by the NSERC postdoctoral fellowship award.

Conflict of Interests: Authors state no conflict of interest.

Ethical approval: The conducted research is not related to either human or animals use.

\section{References}

[1] Yao A., Wang D., Huang W., Fu Q., Rahaman M.N., Day D.E., In Vitro Bioactive Characteristics of Borate-Based Glasses with Controllable Degradation Behavior, J. Am. Ceram. Soc., 2006, 90(1), 303-306.

[2] Huang W., Day D.E., Kittiratanapiboon K., Rahaman M.N., Kinetics and mechanisms of the conversion of silicate (45S5), borate, and borosilicate glasses to hydroxyapatite in dilute phosphate solutions, J. Mater. Sci.: Mater. Med., 2006, 17(7), 583-596.

[3] Fu Q., Rahaman M.N., Fu H., Liu X., Silicate, borosilicate, and borate bioactive glass scaffolds with controllable degradation rate for bone tissue engineering applications. I. Preparation and in vitro degradation, J. Biomed. Mater. Res., Part A, 2010, 95(1), 164-171.

[4] Han X., Day D.E., Reaction of sodium calcium borate glasses to form hydroxyapatite, J. Mater. Sci.: Mater. Med., 2007, 18(9), 1837-1847.

[5] Gu Y., Huang W., Rahaman M.N., In vivo evaluation of scaffolds with a grid-like microstructure composed of a mixture of silicate (13-93) and borate (13-93B3) bioactive glasses, Ceram. Eng. Sci. Proc., 2014, 35(5), 53-64.

[6] Liu X., Xie Z., Zhang C., Pan H., Rahaman M.N., Zhang X., Fu Q., Huang W., Bioactive borate glass scaffolds: in vitro and in vivo evaluation for use as a drug delivery system in the treatment of bone infection, J. Mater. Sci.: Mater. Med., 2010, 21(2), 575-582.

[7] Bi L., Rahaman M.N., Day D.E., Brown Z., Samujh C., Liu X., Mohammadkhah A., Dusevich V., Eick J.D., Bonewald L.F., Effect of bioactive borate glass microstructure on bone regeneration, angiogenesis, and hydroxyapatite conversion in a rat calvarial 
defect model, Acta Biomater., 2013, 9(8), 8015-8026.

[8] Bi L., Zobell B., Liu X., Rahaman M.N., Bonewald L.F., Healing of critical-size segmental defects in rat femora using strong porous bioactive glass scaffolds, Mater. Sci. Eng., C, 2014, 42, 816-824.

[9] O'Connell K., Pierlot C., O'Shea H., Beaudry D., Chagnon M., Assad M., Boyd D., Host responses to a strontium releasing high boron glass using a rabbit bilateral femoral defect model, J. Biomed. Mater. Res., Part B, 2017, 105(7), 1818-1827.

[10] Lin Y., Brown R.F., Jung S.B., Day D.E., Angiogenic effects of borate glass microfibers in a rodent model, J. Biomed. Mater. Res. Part A, 2014, 102(12), 4491-4499.

[11] Zhao S., Li L., Wang H., Zhang Y., Cheng X., Zhou N., Rahaman M.N., Liu Z., Huang W., Zhang C., Wound dressings composed of copper-doped borate bioactive glass microfibers stimulate angiogenesis and heal full-thickness skin defects in a rodent model, Biomaterials., 2015, 53, 379-391.

[12] Chen S., Yang Q., Brow R.K., Liu K., Brow K.A., Ma Y., Shi H., In vitro stimulation of vascular endothelial growth factor by boratebased glass fibers under dynamic flow conditions, Mater. Sci. Eng., C, 2017, 73, 447-455.

[13] Zhou J., Wang H., Zhao S., Zhou N., Li L., Huang W., Wang D., Zhang C., In vivo and in vitro studies of borate based glass microfibers for dermal repairing, Mater. Sci. Eng., C, 2016, 60, 437-445.

[14] Naseri S., Lepry W.C., Nazhat S.N., Bioactive glasses in wound healing: hope or hype?, J. Mater. Chem. B, 2017, 5(31), 6167-6174.

[15] Yao A.H., Wang D.P., Huang W.H., Fu Q., Rahaman M.N., Day D.E., In vitro bioactive characteristics of borate-based glasses with controllable degradation behavior, J. Am. Ceram. Soc., 2007, 90(1), 303-306.

[16] Hasan M.S., Werner-Zwanziger U., Boyd D., Compositionstructure-properties relationship of strontium borate glasses for medical applications, J. Biomed. Mater. Res., Part A, 2015, 103(7), 2344-2354.

[17] MacDonald K., Hanson M.A., Boyd D., Modulation of strontium release from a tertiary borate glass through substitution of alkali for alkali earth oxide, J. Non-Cryst. Solids, 2016, 443, 184-191.

[18] O’Connell K., Werner-Zwanziger U., O’Shea H., Boyd D., High Borate Networks as a Platform to Modulate Temporal Release of Therapeutic Metal Ions Gallium and Strontium, Biomed. Glasses, 2017, 3(1), 18-27.

[19] Lepry W.C., Nazhat S.N., Highly Bioactive Sol-Gel-Derived Borate Glasses, Chem. Mater., 2015, 27(13), 4821-4831.

[20] Naseri S., Lepry W.C., Maisuria V.B., Tufenkji N., Nazhat S.N., Development and characterization of silver-doped sol-gel-derived borate glasses with anti-bacterial activity, J. Non-Cryst. Solids, 2019, 505, 438-446.

[21] Lepry W.C., Naseri S., Nazhat S.N., Effect of processing parameters on textural and bioactive properties of sol-gel-derived borate glasses, J. Mater. Sci., 2017, 52(15), 8973-8985.

[22] Kokubo T., Takadama H., How useful is SBF in predicting in vivo bone bioactivity?, Biomaterials., 2006, 27(15), 2907-2915.

[23] Kokubo T., Kushitani H., Sakka S., Kitsugi T., Yamamuro T., Solutions able to reproduce in vivo surface-structure changes in bioactive glass-ceramic A-W3, J. Biomed. Mater. Res., 1990, 24(6), 721-734.

[24] Aleš H., Lenka J., Ludvík Š., The influence of simulated body fluid composition on carbonated hydroxyapatite formation, Ceram.Silik., 2002, 46(1), 9-14.

[25] Bohner M., Lemaitre J., Can bioactivity be tested in vitro with SBF solution?, Biomaterials., 2009, 30(12), 2175-2179.
[26] Zadpoor A.A., Relationship between in vitro apatite-forming ability measured using simulated body fluid and in vivo bioactivity of biomaterials, Mater. Sci. Eng., C, 2014, 35, 134-143.

[27] Pan H., Zhao X., Darvell B.W., Lu W.W., Apatite-formation ability - Predictor of “bioactivity"?, Acta Biomater., 2010, 6(11), 41814188.

[28] Maçon A.L.B., Kim T.B., Valliant E.M., Goetschius K., Brow R.K., Day D.E., Hoppe A., Boccaccini A.R., Kim I.Y., Ohtsuki C., Kokubo T., Osaka A., Vallet-Regí M., Arcos D., Fraile L., Salinas A.J., Teixeira A.V., Vueva Y., Almeida R.M., Miola M., Vitale-Brovarone C., Verné E., Höland W., Jones J.R., A unified in vitro evaluation for apatite-forming ability of bioactive glasses and their variants, J. Mater. Sci.: Mater. Med., 2015, 26(2), 1-10.

[29] Cerruti M., Bianchi C.L., Bonino F., Damin A., Perardi A., Morterra C., Surface Modifications of Bioglass Immersed in TRIS-Buffered Solution. A Multitechnical Spectroscopic Study, J. Phys. Chem. B, 2005, 109(30), 14496-14505.

[30] Kirste G., Brandt-Slowik J., Bocker C., Steinert M., Geiss R., Brauer D.S., Effect of chloride ions in Tris buffer solution on bioactive glass apatite mineralization, Int. J. Appl. Glass Sci., 2017, 8(4), 438-449.

[31] Al-Noaman A., Rawlinson S.C.F., Hill R.G., The role of $\mathrm{MgO}$ on thermal properties, structure and bioactivity of bioactive glass coating for dental implants, J. Non-Cryst. Solids, 2012, 358(22), 3019-3027.

[32] Varila L., Fagerlund S., Lehtonen T., Tuominen J., Hupa L., Surface reactions of bioactive glasses in buffered solutions, J. Eur. Ceram. Soc., 2012, 32(11), 2757-2763.

[33] Fagerlund S., Hupa L., Hupa M., Comparison of reactions of bioactive glasses in different aqueous solutions, Ceram. Trans., 2010, 218, 101-113.

[34] Rodriguez O., Alhalawani A., Arshad S., Towler M., RapidlyDissolving Silver-Containing Bioactive Glasses for Cariostatic Applications, J Funct Biomater., 2018, 9(2), 28.

[35] Ab llah N., Jamaludin S., Daud Z., Zaludin M., Jamal Z., Idris M., Osman R., Corrosion behavior of Mg-3Zn/bioglass (45S5) composite in simulated body fluid (SBF) and phosphate buffered saline (PBS) solution, AIP Conf. Proc., 2016, 1756, 030001.

[36] Fu Q., Rahaman M.N., Day D.E., Accelerated Conversion of Silicate Bioactive Glass (13-93) to Hydroxyapatite in Aqueous Phosphate Solution Containing Polyanions, J. Am. Ceram. Soc., 2009, 92(12), 2870-2876.

[37] Dziadek M., Zagrajczuk B., Menaszek E., Cholewa-Kowalska K., A new insight into in vitro behaviour of poly ( $\epsilon$ caprolactone)/bioactive glass composites in biologically related fluids, J. Mater. Sci., 2018, 53(6), 3939-3958.

[38] Theodorou G., Goudouri O., Kontonasaki E., Chatzistavrou X., Papadopoulou L., Kantiranis N., Paraskevopoulos K., Comparative bioactivity study of $45 \mathrm{~S} 5$ and $58 \mathrm{~S}$ bioglasses in organic and inorganic environment, Bioceram. Dev. App., 2011, 1, 1-4

[39] Lee J.T.Y., Leng Y., Chow K.L., Ren F., Ge X., Wang K., Lu X., Cell culture medium as an alternative to conventional simulated body fluid, Acta Biomater., 2011, 7(6), 2615-2622.

[40] Rohanová D., Boccaccini A.R., Horkavcová D., Bozděchová P., Bezdička P., Častorálová M., Is non-buffered DMEM solution a suitable medium for in vitro bioactivity tests?, J. Mater. Chem. B, 2014, 2(31), 5068-5076.

[41] Popa A., Stan G., Husanu M., Mercioniu I., Santos L., Fernandes H., Ferreira J., Bioglass implant-coating interactions in synthetic physiological fluids with varying degrees of biomimicry, Int. J. 
Nanomed., 2017, 12, 683-707.

[42] Fu H., Rahaman M.N., Day D.E., Huang W., Long-term conversion of $45 \mathrm{~S} 5$ bioactive glass-ceramic microspheres in aqueous phosphate solution, J. Mater. Sci.: Mater. Med., 2012, 23(5), 1181-1191.

[43] Bingel L., Groh D., Karpukhina N., Brauer D.S., Influence of dissolution medium $\mathrm{pH}$ on ion release and apatite formation of Bioglass ${ }^{\circledR}$ 45S5, Mater. Lett., 2015, 143, 279-282.

[44] Björkvik L., Wang X., Hupa L., Dissolution of Bioactive Glasses in Acidic Solutions with the Focus on Lactic Acid, Int. J. Appl. Glass Sci., 2016, 7(2), 154-163.

[45] Huang W., Rahaman M.N., Day D.E., Li Y., Mechanisms for converting bioactive silicate, borate, and borosilicate glasses to hydroxyapatite in dilute phosphate solutions, Phys. Chem. Glasses, 2006, 47(6), 647-658.

[46] Ning J., Yao A., Wang D., Huang W., Fu H., Liu X., Jiang X., Zhang $\mathrm{X}$., Synthesis and in vitro bioactivity of a borate-based bioglass, Mater. Lett., 2007, 61(30), 5223-5226.

[47] Lu X., Kolzow J., Chen R.R., Du J., Effect of solution condition on hydroxyapatite formation in evaluating bioactivity of B203 containing 45S5 bioactive glasses, Bioact. Mater., 2019, 4, 207 214.

[48] Fu H., Rahaman M.N., Day D.E., Huang W., Effect of pyrophosphate ions on the conversion of calcium-lithium-borate glass to hydroxyapatite in aqueous phosphate solution, J. Mater. Sci.: Mater. Med., 2010, 21(10), 2733-2741.

[49] Marzouk M.A., ElBatal H.A., In vitro bioactivity of soda lime borate glasses with substituted $\mathrm{SrO}$ in sodium phosphate solution, Process Appl. Ceram., 2014, 8(3), 167-177.

[50] Abdelghany A.M., ElBatal H.A., EzzElDin F.M., Bone bonding ability behavior of some ternary borate glasses by immersion in sodium phosphate solution, Ceram. Int., 2012, 38(2), 1105-1113.

[51] Ciraldo F.E., Boccardi E., Melli V., Westhauser F., Boccaccini A.R., Tackling bioactive glass excessive in vitro bioreactivity: Preconditioning approaches for cell culture tests, Acta Biomater., 2018 75, 3-10.

[52] Modglin V.C., Brown R.F., Jung S.B., Day D.E., Cytotoxicity assessment of modified bioactive glasses with MLO-A5 osteogenic cells in vitro, J. Mater. Sci.: Mater. Med., 2013, 24(5), 1191-1199.

[53] Midha S., Kim T.B., van den Bergh W., Lee P.D., Jones J.R., Mitchell C.A., Preconditioned $70530 \mathrm{C}$ bioactive glass foams promote osteogenesis in vivo, Acta Biomater., 2013, 9(11), 9169-9182.

[54] Brunauer S., Emmett P.H., Teller E., Adsorption of gases in multimolecular layers, J. Am. Chem. Soc., 1938, 60(2), 309-319.

[55] Joyner L.G., Barrett E.P., Skold R., The Determination of Pore Volume and Area Distributions in Porous Substances. II. Comparison between Nitrogen Isotherm and Mercury Porosimeter Methods, J. Am. Chem. Soc., 1951, 73(7), 3155-3158.

[56] Lepry W.C., Smith S., Nazhat S.N., Effect of sodium on bioactive sol-gel-derived borate glasses, J. Non-Cryst. Solids, 2018, 500, 141-148.

[57] Kamitsos E., Karakassides M., Chryssikos G.D., A vibrational study of lithium borate glasses with high Li2O content, Phys. Chem. Glasses, 1987, 28(5), 203-209.

[58] Deliormanlı A.M., In vitro assessment of degradation and bioactivity of robocast bioactive glass scaffolds in simulated body fluid, Ceram. Int., 2012, 38(8), 6435-6444.

[59] Kamitsos E., Karakassides M., Chryssikos G.D., Vibrational spectra of magnesium-sodium-borate glasses. 2. Raman and midinfrared investigation of the network structure, J. Phys. Chem. 1987, 91(5), 1073-1079.
[60] Gautam C., Yadav A.K., Singh A.K., A Review on Infrared Spectroscopy of Borate Glasses with Effects of Different Additives, ISRN Ceram., 2012, 17.

[61] Agathopoulos S., Tulyaganov D., Ventura J., Kannan S., Karakas sides M., Ferreira J., Formation of hydroxyapatite onto glasses of the $\mathrm{CaO}-\mathrm{MgO}-\mathrm{SiO} 2$ system with $\mathrm{B2O}, \mathrm{Na2O}, \mathrm{CaF} 2$ and P2O5 additives, Biomaterials, 2006, 27(9), 1832-1840.

[62] Balachandera L., Ramadevudub G., Shareefuddina M., Sayannac R., Venudharc Y., IR analysis of borate glasses containing three alkali oxides, ScienceAsia, 2013, 39(3), 278-283.

[63] Carta D., Qiu D., Guerry P., Ahmed I., Abou Neel E.A., Knowles J.C., Smith M.E., Newport R.J., The effect of composition on the structure of sodium borophosphate glasses, J. Non-Cryst. Solids, 2008, 354(31), 3671-3677.

[64] Rey C., Shimizu M., Collins B., Glimcher M.J., Resolutionenhanced fourier transform infrared spectroscopy study of the environment of phosphate ion in the early deposits of a solid phase of calcium phosphate in bone and enamel and their evolution with age: 2 . Investigations in the nu3PO4 domain, Calcif. Tissue. Int., 1991, 49(6), 383-388.

[65] Nelson D., Featherstone J., Preparation, analysis, and characterization of carbonated apatites, Calcif. Tissue. Int., 1981, 34S6981.

[66] Chickerur N., Tung M., Brown W., A mechanism for incorporation of carbonate into apatite, Calcif. Tissue. Int., 1980, 32(1), 55-62.

[67] LeGeros R.Z., The unit-cell dimensions of human enamel apatite: effect of chloride incorporation, Arch. Oral Biol., 1975, 20(1), 6371.

[68] Fowler B., Moreno E., Brown W., Infra-red spectra of hydroxyapatite, octacalcium phosphate and pyrolysed octacalcium phosphate, Arch. Oral Biol., 1966, 11(5), 477-492.

[69] Gibson I., Rehman I., Best S., Bonfield W., Characterization of the transformation from calcium-deficient apatite to $\beta$-tricalcium phosphate, J. Mater. Sci.: Mater. Med., 2000, 11(9), 533-539.

[70] Chester R., Elderfield H., The application of infra-red absorption spectroscopy to carbonate mineralogy, Sedimentology, 1967, 9(1), 5-21.

[71] Andersen F.A., Brecevic L., Infrared spectra of amorphous and crystalline calcium carbonate, Acta Chem. Scand, 1991, 45(10), 1018-1024.

[72] Miguez-Pacheco V., Hench L.L., Boccaccini A.R., Bioactive glasses beyond bone and teeth: Emerging applications in contact with soft tissues, Acta Biomater., 2015, 131-15.

[73] Gomori G., Buffers in the Range of pH 6.5 to 9.6, Proc Soc Exp Biol Med., 1946, 62(1), 33-34.

[74] Good N.E., Winget G.D., Winter W., Connolly T.N., Izawa S., Singh R.M., Hydrogen ion buffers for biological research, Biochemistry, 1966, 5(2), 467-477.

[75] Clark A., Hench L., Paschall H., The influence of surface chemistry on implant interface histology: a theoretical basis for implant materials selection, J. Biomed. Mater. Res., 1976, 10(2), 161-174.

[76] Clark Jr A., Pantano Jr C., Hench L., Auger spectroscopic analysis of bioglass corrosion films, J. Am. Ceram. Soc., 1976, 59(1-2), 37-39.

[77] Hench L., Stability of ceramics in the physiological environment, Fundamental aspects of biocompatibility, 1981, 167-85.

[78] Rohanová D., Boccaccini A.R., Yunos D.M., Horkavcová D., Březovská I., Helebrant A., TRIS buffer in simulated body fluid distorts the assessment of glass-ceramic scaffold bioactivity, Acta Biomater., 2011, 7(6), 2623-2630. 
[79] Kim H.M., Miyazaki T., Kokubo T., Nakamura T., Revised simulated body fluid, Key Eng. Mater., 2001, 192, 47-50.

[80] Oyane A., Kim H.M., Furuya T., Kokubo T., Miyazaki T., Nakamura T., Preparation and assessment of revised simulated body fluids, J. Biomed. Mater. Res., Part A, 2003, 65(2), 188-195.

[81] Cerruti M., Greenspan D., Powers K., Effect of pH and ionic strength on the reactivity of Bioglass 45S5, Biomaterials, 2005 , 26(14), 1665-1674.

[82] Mneimne M., Hill R.G., Bushby A.J., Brauer D.S., High phosphate content significantly increases apatite formation of fluoridecontaining bioactive glasses, Acta Biomater., 2011, 7(4), 18271834.

[83] Wetzel R., Brauer D.S., Apatite formation of substituted Bioglass 45S5: SBF vs. Tris, Mater. Lett., 2019, 126760.

[84] Pereira M.M., Clark A.E., Hench L.L., Calcium phosphate formation on sol-gel-derived bioactive glasses in vitro, J. Biomed. Mater. Res., 1994, 28(6), 693-698.

[85] Tournié A., Majérus O., Lefèvre G., Rager M.N., Walmé S., Caurant D., Barboux P., Impact of boron complexation by Tris buffer on the initial dissolution rate of borosilicate glasses, J Colloid Interface Sci., 2013, 400, 161-167.

[86] Sepulveda P., Jones J.R., Hench L.L., In vitro dissolution of melt-derived $45 \mathrm{~S} 5$ and sol-gel derived $58 \mathrm{~S}$ bioactive glasses, J. Biomed. Mater. Res., 2002, 61(2), 301-311.

[87] Mozafari M., Banijamali S., Baino F., Kargozar S., Hill R.G., Calcium carbonate: Adored and ignored in bioactivity assessment, Acta Biomater., 2019, 91, 35-47.

[88] Doucet J., Tonkopi E., Nuschke A., Tremblay M., Brewer K., Beyea S., Filiaggi M., Abraham R., Werner-Zwanziger U., Boyd D., Multimodal imageability and degradation characteristics of highborate glass systems for transient embolization, J. Non-Cryst. Solids, 2019, 510, 26-35.

[89] Li H., Sun S.-r., Yap J.Q., Chen J.-h., Qian Q., 0.9\% saline is neither normal nor physiological, J Zhejiang Univ. Sci. B, 2016, 17(3), 181187.

[90] Zeitler T.R., Cormack A.N., Interaction of water with bioactive glass surfaces, J. Cryst. Growth, 2006, 294(1), 96-102.

[91] Tilocca A., Cormack A.N., Exploring the surface of bioactive glasses: water adsorption and reactivity, J. Phys. Chem. C, 2008, 112(31), 11936-11945.

[92] Naseri S., Lepry W.C., Li W., Waters K.E., Boccaccini A.R., Nazhat S.N., $45 S 5$ bioactive glass reactivity by dynamic vapour sorption, J. Non-Cryst. Solids, 2016, 432, Part A, 47-52.

[93] Goetschius K.L., Beuerlein M.A., Bischoff C.M., Brow R.K., Dissolution behavior of ternary alkali-alkaline earth-borate glasses in water, J. Non-Cryst. Solids, 2018, 487, 12-18.

[94] O’Connell K., Werner-Zwanziger U., O’Shea H., Boyd D., High Borate Networks as a Platform to Modulate Temporal Release of Therapeutic Metal Ions Gallium and Strontium, Biomed. Glasses, 2017, 3(1), 18-29.

[95] Chen Q.-Z., Li Y., Jin L.-Y., Quinn J.M., Komesaroff P.A., A new sol-gel process for producing $\mathrm{Na} 20$-containing bioactive glass ceramics, Acta Biomater., 2010, 6(10), 4143-4153.

[96] Lusvardi G., Malavasi G., Menabue L., Aina V., Morterra C., Fluoride-containing bioactive glasses: surface reactivity in simulated body fluids solutions, Acta Biomater., 2009, 5(9), 35483562.

[97] Weir C., Lippincott E., Infrared studies of aragonite, calcite, and vaterite type structures in the borates, carbonates, and nitrates, J. Res. Natl. Bur. Stand. US, Sect. A, 1961, 65, 173-183.
[98] Donoghue M., Hepburn P.H., Ross S.D., Factors affecting the infrared spectra of planar anions with D3h, symmetry-V: The origin of the splitting of the out-of-plane bending mode in carbonates and nitrates, Spectrochim. Acta A, 1971, 27(7), 1065-1072.

[99] Song Y., Hahn H.H., Hoffmann E., Effects of solution conditions on the precipitation of phosphate for recovery: A thermodynamic evaluation, Chemosphere, 2002, 48(10), 1029-1034.

[100] Tsuru K., Otsu A., Maruta M., Valanezhad A., Kawachi G., Takeuchi A., Matsuya S., Kunio I., Calcite Bone Substitute Prepared from Calcium Hydroxide Compact Using Heat-treatment under Carbon Dioxide Atmosphere, Key Eng. Mater., 2012, 493, 166-169.

[101] Fujita Y., Yamamuro T., Nakamura T., Kotani S., Ohtsuki C., Kokubo T., The bonding behavior of calcite to bone, J. Biomed. Mater. Res., 1991, 25(8), 991-1003.

[102] Hench L.L., Polak J.M., Third-generation biomedical materials, Science, 2002, 295(5557), 1014-1017.

[103] Vuola J., Göransson H., Böhling T., Asko-Seljavaara S., Bone marrow induced osteogenesis in hydroxyapatite and calcium carbonate implants, Biomaterials, 1996, 17(18), 1761-1766.

[104] Redey S., Razzouk S., Rey C., Bernache-Assollant D., Leroy G., Nardin M., Cournot G., Osteoclast adhesion and activity on synthetic hydroxyapatite, carbonated hydroxyapatite, and natural calcium carbonate: relationship to surface energies, J. Biomed. Mater. Res., Part A, 1999, 45(2), 140-147.

[105] Monchau F., Lefevre A., Descamps M., Belquin-Myrdycz A., Laffargue P., Hildebrand H., In vitro studies of human and rat osteoclast activity on hydroxyapatite, $\beta$-tricalcium phosphate, calcium carbonate, Biomol. Eng., 2002, 19(2-6), 143-152.

[106] Jones J.R., Sepulveda P., Hench L.L., Dose-dependent behavior of bioactive glass dissolution, J. Biomed. Mater. Res., Part A, 2001, 58(6), 720-726.

[107] Cannillo V., Chiellini F., Fabbri P., Sola A., Production of Bioglass ${ }^{\circledR}$ 45S5-Polycaprolactone composite scaffolds via saltleaching, Compos. Struct., 2010, 92(8), 1823-1832.

[108] Mačković M., Hoppe A., Detsch R., Mohn D., Stark W.J., Spiecker E., Boccaccini A., Bioactive glass (type 45S5) nanoparticles: in vitro reactivity on nanoscale and biocompatibility, J. Nanopart. Res., 2012, 14(7), 966.

[109] Deliormanlı A.M., Size-dependent degradation and bioactivity of borate bioactive glass, Ceram. Int., 2013, 39(7), 8087-8095.

[110] Jung S.B., Borate based bioactive glass scaffolds for hard and soft tissue engineering, Missouri University of Science and Technology Doctoral Dissertations, 2010.

[111] Lepry W.C., Smith S., Liverani L., Boccaccini A.R., Nazhat S.N., Acellular Bioactivity of Sol-Gel Derived Borate GlassPolycaprolactone Electrospun Scaffolds, Biomed. Glasses, 2016, 2(1), 88-98.

[112] Punnia-Moorthy A., Evaluation of pH changes in inflammation of the subcutaneous air pouch lining in the rat, induced by carrageenan, dextran and Staphylococcus aureus, J. Oral Pathol., 1987, 16(1), 36-44.

[113] George J.L., Brow R.K., In-situ characterization of borate glass dissolution kinetics by $\mu$-Raman spectroscopy, J. Non-Cryst. Solids, 2015, 426, 116-124.

[114] da Cruz L.P.D., Hill R.G., Chen X., Gillam D.G., Dentine Tubule Occlusion by Novel Bioactive Glass-Based Toothpastes, Int. J. Dent., 2018, 5701638.

[115] Deliormanlı A.M., Investigation of in vitro mineralization of silicate-based $45 \mathrm{~S} 5$ and $13-93$ bioactive glasses in artificial saliva 
for dental applications, Ceram. Int., 2017, 43(4), 3531-3539.

[116] Zhong Y., Liu J., Li X., Yin W., He T., Hu D., Liao Y., Yao X., Wang Y., Effect of a novel bioactive glass-ceramic on dentinal tubule occlusion: an in vitro study, Aust. Dent. J., 2015, 60(1), 96-103.
[117] Fusayama T., Katayori T., Nomoto S., Corrosion of gold and amalgam placed in contact with each other, J. Dent. Res., 1963, 42(5), 1183-1197. 